\title{
PENGARUH PERSEPSI SISWA TENTANG KETERAMPILAN MENGAJAR GURU DAN FASILITAS BELAJAR SISWA TERHADAP PRESTASI BELAJAR SISWA KELAS XI SMA NEGERI 1 BATANG KUIS TAHUN PELAJARAN 2015/2016
}

\author{
Ainul Mardhiyah ${ }^{1)}$, Susanto Saputra Waruwu ${ }^{2)}$ \\ ${ }^{1)}$ Fakultas Ekonomi, Universitas Negeri Medan \\ 2) Fakultas Ekonomi, Universitas Negeri Medan
}

\begin{abstract}
Prestasi belajar merupakan indikator yang penting untuk mengukur keberhasilan proses belajar mengajar. Prestasi belajar banyak dipengaruhi oleh benyak faktor, diantaranya keterampilan mengajar guru dan fasilitas belajar siswa. Masalah dalam penelitian ini yaitu masih rendahnya prestasi belajar siswa kelas XI pada mata pelajaran ekonomi.Tujuan penelitian ini dilakukan untuk mengetahui Pengaruh Persepsi Siswa Tentang Keterampilan Mengajar Guru dan Fasilitas Belajar Siswa Terhadap Prestasi Belajar Siswa Kelas XI SMA Negeri 1 Batang Kuis Tahun Pelajaran 2015/2016. Penelitian ini dilaksanakan di SMA Negeri 1 Batang Kuis dengan populasi sebanyak 146 siswa dan sampel yang diambil sebanyak 66 siswa dengan teknik random sampling dan instrumen yang digunakan dalam penelitian ini berupa angket. Hasil pengujian dapat disimpulkan bahwa keterampilan mengajar guru dan fasilitas belajar siswa yang baik akan berpotensi meningkatkan prestasi belajar siswa.
\end{abstract}

Keywords: Keterampilan Mengajar Guru, Fasilitas Belajar, Prestasi Belajar. 


\section{PENDAHULUAN}

Pendidikan merupakan proses yang sangat menentukan dalam pencapaian kualitas terbaik sumber daya manusia karena cukup disadari bahwa kemajuan masyarakat dapat dilihat dari perkembangan pendidikannya.Tujuan pendidikan ialah untuk meningkatkan pengetahuan dan keterampilan siswa, sehingga mampu menjadi individu yang memiliki kualitas yang maksimal untuk menguasai kemajuan ilmu pengetahuan dan teknologi yang berkembang di masyarakat serta mampu menjadi pribadi yang tangguh dan ikut serta membangun negaranya.

Sasaran utama pendidikan adalah peningkatan kualitas sumber daya manusia. Karena kualitas sumber daya manusia merupakan aspek yang sangat penting untuk mendorong kemajuan suatu Negara. Maka langkah pertama yang harus dijalankan adalah meningkatkan kualitas siswa yang bertugas sebagai penerus-penerus bangsa.

Keberhasilan siswa dalam menangkap pelajaran yang disampaikan oleh seorang guru sangat tergantung pada keterampilan seorang guru tersebut dalam mengajar. Banyak faktor yang mempengaruhi prestasi belajar siswa, antara lain faktor siswa itu sendiri, lingkungan sekitar, faktor guru dan tingkat kesukaran materi pelajaran serta fasilitas belajar yang kurang memadai.

Guru terampil sebaiknya melakukan berbagai upaya untuk peningkatan prestasi belajar siswa. Hal tersebut merupakan tanggung jawab semua guru dalam memperoleh kualitas sumber daya manusia. Untuk mewujudkan hal di atas seorang guru dituntut untuk memiliki ketrampilan mengajar. Rusman (2014:80) menyatakan keterampilan dasar mengajar yang harus ada pada seorang tenaga pengajar atau pendidik dapat dibedakan menjadi sembilan jenis keterampilan. Keterampilan dasar mengajar tersebut adalah sebagai berikut : keterampilan menjelaskan, keterampilan bertanya, keterampilan menggunakan variasi stimulus, keterampilan memberi penguatan, keterampilan membuka, keterampilan menutup, keterampilan mengajar kelompok kecil dan perseorangan, keterampilan mengelola kelas, dan keterampilan membimbing diskusi kelompok kecil. Dengan demikian keterampilan mengajar tersebut harus senantiasa dikembangkan oleh guru untuk mencapai tujuan pengajaran.
Disamping keterampilan guru dalam proses belajar mengajar, faktor yang mempengaruhi prestasi belajar siswa adalah fasilitas belajar. Mutu pendidikan yang dikembangkan agar tetap baik, maka perlu diadakan dan diciptakan suatu fasilitas yang dapat membantu dan mendorong prestasi belajar yang baik hendaknya tersedia fasilitas belajar yang memadai antara lain tempat belajar, alat, waktu dan lain-lain. Jadi pada prinsipnya fasilitas belajar adalah segala sesuatu yang memudahkan untuk belajar. Fasilitas yang dimaksud dalam hal ini adalah sarana dan prasarana belajar yang tersedia di sekolah yang mendukung belajar siswa seperti ruang / tempat belajar, alat-alat belajar, penerangan belajar, suasana tempat belajar, perpustakaan, laboratorium dan ruang praktek. Dengan tersedianya fasilitas yang memadai siswa diharapkan memperoleh hasil yang baik.

Berdasarkan pengamatan penulis pada saat observasi di SMA Negeri 1 Batang Kuis, terlihat bahwa guru sebenarnya menguasai materi pelajaran, namun sulit menyalurkan pengetahuannya kepada siswa. Hal ini terlihat dari siswa-siswi tidak ikut berpartisipasi dalam pelajaran. Ketika guru memulai topik pelajaran baru, tidak adanya pengulangan terhadap topik sebelumnya untuk sekedar menyegarkan ingatan para siswa, dan saat proses belajar mengajar berlangsung tidak adanya penguatan yang diberikan guru terhadap siswa yang menjawab ataupun bagi siswa yang belum bisa menjawab pertanyaan dari guru. Faktor terakhir yang menarik perhatian peneliti adalah guru masih menggunakan metode ceramah, tanpa menggunakan media ataupun model pembelajaran. Hal ini menjadikan persepsi siswa terhadap keterampilan mengajar guru tersebut menjadi buruk. Sehingga membuat siswa menjadi bosan dan tidak antusias memberikan perhatiaannya pada saat proses belajar mengajar. Jika dilihat dari segi fasilitas belajar di SMA N 1 Batang Kuis sebagian besar sudah terlengkapi, tetapi kualitas dan kuantitas yang dimiliki belum cukup baik untuk menunjang proses belajar mengajar. Karena kualitas dan kuantitas dari fasilitas tersebut kurang memadai, maka siswa tidak dapat menggunakan fasilitas tersebut secara maksimal. Kedua faktor di atas sangat berpengaruh terhadap prestasi yang dicapai oleh siswa. Masih bayak siswa yang memperoleh nilai di bawah KKM (Kriteria Ketuntasan Mimimum) yaitu 74. Sebanyak 97 orang siswa 
atau 65\%yang tuntas dan sisanya adalah 49 orang siswa atau $35 \%$ yang tidak tuntas untuk mata pelajaran ekonomi di kelas XI IS SMA N 1 Batang Kuis.

Guru merupakan orang yang terlibat langsung dengan siswa dalam proses belajar mengajar. Seorang guru harus memiliki keterampilan mengajar karena guru adalah penetu hasil belajar siswa. Tugas dan tanggung jawab guru sebagai pengajar, pendidik dan pembimbing lebih menekankan kepada tugas dalam merencanakan dan melaksanakan pengajaran serta memberikan bantuan kepada siswa untuk memecahkan masalah-masalah yang dihadapinya.

Dalam hal ini guru dituntut memiliki seperangkat pengetahuan, dan keterampilan teknis mengajar, di samping menguasai ilmu atau bahan yang akan diajarkannya. Selain penyampaian ilmu pengetahuan, melainkan juga menyangkut pembinaan kepribadian dan pembentukan nilai-nilai para siswa. Mulyasa (2009:169) mengemukankan bahwa "keterampilan mengajar merupakan kompetensi profesional yang cukup kompleks, sebagai integrasi dari berbagai kompetensi guru secara utuh dan menyeluruh".

Syah (2007:13) mengemukakan bahwa :Keterampilan adalah kemampuan melakukan pola-pola tingkah laku yang komplek dan tersusun rapi secara mulus sesuai dengan keadaan umum mencapai hasil tertentu keterampilan bukan hanya meliputi gerakan motorik melainkan juga pengejawatan fungsi mental yang bersifat kognitif. Konotasinya pun luas sehingga sampai pada mempengaruhi atau mendayagunakan orang lain.

Selain keterampilan mengajar guru, faktor yang mempengaruhi prestasi belajar adalah fasilitas belajar. Suatu kegiatan akan bejalan dengan baik bila tersedia fasilitas belajar yang mendukung kegiatan tersebut. Secara umum fasilitas merupakan alat yang digunakan untuk melakukan sesuatu hal yang akan mempermudah suatu pekerjaan tersebut. Fasilitas mempunyai peranan penting dalam meningkatkan hasil belajar siswa, sebagaimana yang dikemukakan oleh Gie (2002:34) bahwa: Adanya fasilitas yang baik dapat menciptakan kondisi belajar yang efektif dan menyenangkan. Fasilitas adalah segenap kebutuhan yang diperlukan untuk menyelesaikan pekerjaanpekerjaan dalam suatu usaha manusia.
Berdasarkan pendapat diatas dapat disimpulkan bahwa persepsi adalah pandangan, atau penilaian seseorang terhadap suatu objek atau peristiwa melalui penginderaan dengan adanya berbagai stimulus. Demikian halnya dalam proses belajar mengajar, dimana melalui penginderaan ataupun pengalaman siswa bersama guru, maka siswa bisa memberi tanggapan, ataupun penilaian bagaimana keterampilan guru mengajar.

Dari pendapat ahli tersebut prestasi belajar dibidang pendidikan adalah hasil dari pengukuran terhadap peserta didik yang menjadi faktor kognitif, afektif dan psikomotorik setelah mengikuti proses pembelajaran yang diukur dengan menggunakan instrumen test, atau instrumen relavan. Jadi prestasi belajar adalah hasil pengukuran dari penilaian usaha belajar yang dinyatakan dalam bentuk simbol, huruf, maupun kalimat yang menceritakan hasil yang sudah dicapai oleh setiap anak pada periode tertentu.

Hasil akhir dari proses kegiatan belajar mengajar adalah prestasi belajar. Dalam Kamus Besar Bahasa Indonesia, yang dimaksud dengan prestasi adalah hasil yang telah dicapai (dilakukan, dikerjakan dan sebagainya) sedangkan belajar adalah sebuah usaha untuk memperoleh kepandaian atau ilmu.

\section{METODE PENELITIAN}

Penelitian ini dilakukan di SMA Negeri 1 Batang Kuis. Populasi dalam penelitian ini adalah seluruh siswa kelas XI SMA Negeri 1 Batang Kuis yang berjumlah 146 orang. Adapun sampel dalam penelitian ini adalah siswa kelas XI IS 1,XI IS 2,XI IS 3, XI IS 4 yang berjumlah 66 siswa. Sampel diambil dengan teknik random (acak) sampling. Sampel yang akan diambil sebesar $45 \%$ dari populasi. Maka yang menjadi sampel ditetapkan sebanyak $45 \%$ x 146=66 orang.

Variabel bebas yang dikaji dalam penelitian ini adalah keterampilan mengajar guru (X1) dan fasilitas belajar (X2) sedangkan variabel terikatnya adalah prestasi belajar (Y). Teknik pengumpulan data pada penelitian ini dilakukan dengan metode kuesioner atau angket dan dokumentasi. Metode analisis data adalah suatu metode yang digunakan untuk mengolah hasil penelitian guna memperoleh suatu kesimpulan. Uji validitas angket menggunakan rumus Product Moment Pearson, dan dan 
reliabilitasnya dihitung dengan rumus Cronbach Alpha. Analisis data menggunakan Uji Asumsi Klasik, Regresi Linear Berganda, Koefisien Determinasi, dan uji hipotesis dengan uji t dan uji F.

\section{HASIL DAN PEMBAHASAN}

Berdasarkan perhitungan regresi linear berganda diperoleh $\mathrm{Y}=31,579+0,248 \mathrm{X} 1+$ 0,435X2. Konstanta (a)yaitu 31,579 dapat diartikan bahwa prestasi belajar (Y) akan bernilai 31,579pada saat keterampilan mengajar guru (X1), dan fasilitas belajar siswa (X2) bernilai nol (asumsi faktor lain konstan).

Dari koefisien pada perhitungan regresi linear berganda, keterampilan mengajar guru (X1) sebesar 0,248 artinya jika keterampilan mengajar guru mengalami kenaikan satu satuan, maka prestasi belajar (Y) akan mengalami peningkatan sebesar 0,248 satuan dengan asumsi variabel independen lainnya bernilai tetap. Sedangkan koefisien pada perhitungan regresi linear berganda, fasilitas belajar siswa (X2) sebesar 0,435 artinya jika fasilitas belajar siswa mengalami kenaikan satu satuan, maka prestasi belajar (Y) akan mengalami peningkatan sebesar 0,435 satuan dengan asumsi variabel independen lainnya bernilai tetap.

Dari hasil penelitian di atas membuktikan bahwa hipotesis yang menyatakan bahwa jika thitung > ttabel maka hipotesis diterima, dimana dari hasil penelitian diperoleh bahwa keterampilan mengajar guru mempunyai nilai thitung sebesar 2,687 dengan signifikansi 0,009 sedangkan nilai ttabel pada tingkat kepercayaan 0,05 sebesar 1,669. Dari penjelasan di atas dapat disimpulkan bahwa nilai thitung > ttabel $(2,687>1,669)$ maka hipotesis diterima yaitu keterampilan mengajar guru berpengaruh positif dan signifikan terhadap prestasi belajar siswa kelas XI IS SMA Negeri 1 Batang Kuis Tahun Pembelajaran 2015/2016.

Sedangkan variabel fasilitas belajar siswa mempunyai nilai thitung sebesar 2,833 dengan signifikansi 0,006 sedangkan nilai ttabel pada tingkat kepercayaan 0,05 sebesar 1,669. Dari penjelasan di atas dapat disimpulkan bahwa thitung > ttabel $(2,833>1,669)$. Maka hipotesis diterima yaitu fasilitas belajar siswa berpengaruh positif dan signifikan terhadap prestasi belajar siswa kelas XI IS SMA Negeri 1 Batang Kuis Tahun Pembelajaran 2015/2016.

Berdasarkan hasil perhitungan uji $\mathrm{F}$ diperoleh nilai Fhitung sebesar 14,159 dengan signifikansi sebesar 0,000 sedangkan Ftabel pada tingkat kepecayaan 0,05 sebesar 3,14. Dari penjelasan di atas dapat disimpulkan bahwa nilai Fhitung > Ftabel (14,159> 3,14). Maka hipotesis diterima yaitu ada pengaruh yang positif dan signifikan keterampilan mengajar guru dan fasilitas belajar siswa terhadap prestasi belajar siswa kelas XI IS SMA Negeri 1 Batang Kuis Tahun Pembelajaran 2015/2016.

Hasil koefisien determinasi (R2) adalah 0,310 . Nilai tersebut berarti bahwa sekitar $31 \%$ prestasi belajar ekonomi siswa kelas XI IS SMA Negeri 1 Batang Kuis dapat dijelaskan melalui variabel keterampilan mengajar guru dan fasilitas belajar siswa, serta sisanya 69\% dipengaruhi oleh variabel-variabel lain di luar penelitian ini.

\section{KESIMPULAN}

Berdasarkan hasil pengujian hipotesis keterampilan mengajar guru berpengaruh positif dan signifikan terhadap prestasi belajar siswa kelas XI IS SMA Negeri 1 Batang Kuis T.P. 2015/2016. Fasilitas belajar siswa berpengaruh positif dan signifikan terhadap prestasi belajar siswa kelas XI IS SMA Negeri 1 Batang Kuis T.P 2015/2016. Terdapat pengaruh yang positif dan signifikan keterampilan mengajar guru dan fasilitas belajar siswa terhadap prestasi belajar siswa kelas XI IS SMA Negeri 1 Batang Kuis T.P. 2015/2016.

Saran

$$
\text { Dengan memahami tentang }
$$
keterampilan mengajar guru memberikan pengaruh yang positif dan signifikan terhadap prestasi belajar ekonomi siswa, guru harus lebih meningkatkan sembilan keterampilan dasar mengajar guru dalam proses kegiatan belajar mengajar. Guru harus lebih banyak menggunakan variasi dalam mengajar baik penggunaan model maupun media pembelajaran, guru harus setiap saat memberi penguatan seperti pujian dalam proses kegiatan belajar, guru juga harus mampu memanajemen kelas agar lebih kondusif dan guru memberikan tugas baik individu maupun tugas kelompok sebagai umpan balik dari hasil proses belajar mengajar.

Dengan memahami tentang fasilitas belajar memberikan pengaruh yang positif dan signifikan terhadap prestasi belajar siswa, pihak sekolah, guru, dan orang tua hendaknya meningkatkan kuantitas dan kualitas fasilitas sekolah agar mendukung proses kegiatan belajar mengajar di sekolah. 
Para peneliti berikutnya diharapkan

untuk mengadakan penelitian dengan populasi yang lebih diperluas dan menambah jumlah variabel, karena masih banyak faktor lain yang mempengaruhi prestasi belajar.

\section{REFERENSI}

Arikunto, Suharsimi. 2010. Prosedur Penelitian. Jakarta : Rineka Cipta.

Dimyati dan Mudjiono. Belajar \& Pembelajaran. Jakarta : Rineka Cipta.

Djamarah, Syaiful Bahri. 2011. Psikologi Belajar. Jakarta : Rineka Cipta.

Mulyasa. 2009. Menjadi Guru Profesional. Bandung : PT Remaja Rosdakarya.

Rusman. 2014. Model Model Pembelajaran. Jakarta : Rajawali Pers.

Slameto. 2013. Belajar dan Faktor Faktor Yang Mempengaruhi. Jakarta : Rineka Cipta.

Sugiyono. 2012. Metode Penelitian Pendidikan. Bandung : Alfabeta.

Suryosubroto. B. 2002. Proses Belajar Mengajar Di Sekolah. Jakarta : PT. Rineka Cipta. 